\title{
Steam gasification of wood char and the effect of hydrogen inhibition on the chemical
} kinetics

Barrio, M.; Gøbel, Benny; Risnes, H.; Henriksen, Ulrik Birk; Hustad, J. E.; Sørensen, L. H.

Published in:

Progress in Thermochemical Biomass Conversion

Publication date:

2000

Document Version

Early version, also known as pre-print

Link back to DTU Orbit

Citation (APA):

Barrio, M., Gøbel, B., Risnes, H., Henriksen, U. B., Hustad, J. E., \& Sørensen, L. H. (2000). Steam gasification of wood char and the effect of hydrogen inhibition on the chemical kinetics. In Progress in Thermochemical Biomass Conversion

\section{General rights}

Copyright and moral rights for the publications made accessible in the public portal are retained by the authors and/or other copyright owners and it is a condition of accessing publications that users recognise and abide by the legal requirements associated with these rights.

- Users may download and print one copy of any publication from the public portal for the purpose of private study or research.

- You may not further distribute the material or use it for any profit-making activity or commercial gain

- You may freely distribute the URL identifying the publication in the public portal 


\title{
Steam gasification of wood char and the effect of hydrogen inhibition on the chemical kinetics.
}

\author{
M. Barrio, B. Gøbel ${ }^{+}$, H. Risnes, U. Henriksen ${ }^{+}$, J.E. Hustad and L.H. \\ Sørensen* \\ Norwegian University of Science and Technology, Department of \\ Thermal Energy and Hydro Power, 7491 Trondheim, Norway \\ ${ }^{+}$Technical University of Denmark, Department of Energy Engineering, \\ Nils Koppel Allé, DTU-Building 403, DK-2800 Kongens Lyngby \\ *ReaTech c/o Centre for Advanced Technology (CAT), Postbox 30, \\ DK-4000 Roskilde
}

\begin{abstract}
Gasification kinetics parameters have been derived for birch and beech char samples $(45 \mu \mathrm{m}<\mathrm{d}<60 \mu \mathrm{m})$ pyrolysed under identical conditions. Reactivity experiments were made in steam-hydrogen-nitrogen mixtures at atmospheric pressure. Reactivity profiles have been obtained in the temperature range from $750{ }^{\circ} \mathrm{C}$ to $950{ }^{\circ} \mathrm{C}$, for $\mathrm{H}_{2} \mathrm{O}$ partial pressures of $0.05,0.1,0.2,0.5$ and 1.0 bar and $\mathrm{H}_{2}$ partial pressures of $0.1,0.2$ and 0.3 bar. Assuming $\mathrm{n}^{\text {th }}$ order kinetics for pure steam experiments, the activation energy and the reaction order are $E=211 \mathrm{~kJ} / \mathrm{mol}$ and $\mathrm{n}=0.51$ for beech and $\mathrm{E}=237 \mathrm{~kJ} / \mathrm{mol}$ and $\mathrm{n}=0.57$ for birch. A kinetic expression based on LangmuirHinshelwood kinetics fairly describes the observed hydrogen inhibition effect on the steam-carbon reaction. The differences between the kinetics determined for the two fuels are relatively small and partly due to the origin and quality of the raw wood. The kinetic parameters obtained are presented using a kinetic compensation diagram; they are compared with literature data and discussed. The influence of the calculation procedure on the results is also discussed. It is found that the data evaluation procedure mostly influences the pre-exponential factor and less the activation energy and reaction order.
\end{abstract}

\section{INTRODUCTION}

The gasification process requires an oxidising agent that provides oxygen for the formation of $\mathrm{CO}$ from solid fuel. The oxidising, or gasifying, agents are air, oxygen, steam and $\mathrm{CO}_{2} . \mathrm{CO}_{2}$ is produced during the pyrolysis and early oxidation processes and generally not externally added. The most common agent is air because of its availability at zero cost. Air, though cheap, is not a perfect agent because of its nitrogen content. The product gas from air gasification has generally a low heating value of 4-7 MJ/ $\mathrm{Nm}^{3}$. Oxygen gasification produces a higher heating value $\left(10-18 \mathrm{MJ} / \mathrm{Nm}^{3}\right)$ but has a drawback due to the high production cost of oxygen.

Steam is another alternative. It also generates a medium calorific value gas $\left(10-14 \mathrm{MJ} / \mathrm{Nm}^{3}\right)$ and moreover increases the hydrogen content of the product gas. The presence of steam is important in case of further catalytic upgrading of the product gas $^{1}$. Steam gasification is however a highly endothermic reaction and requires a temperature above $800{ }^{\circ} \mathrm{C}$ to take place ${ }^{2}$ if no catalyst is present ${ }^{3,4}$. The heat required for the reaction has to be transferred either by partial char combustion in the same reactor -mixing $\mathrm{H}_{2} \mathrm{O}$ with oxygen/air ${ }^{1,5}$ - or by indirect heating ${ }^{6,7}$. 
Because of biomass moisture, and steam from pyrolysis in downdraft gasification, steam will always be present in gasification whether it is used or not as a gasification agent. Hydrogen is one of the products of steam gasification and its effect on the reaction is also relevant. Some kinetic data for steam gasification of biomass have been published $2,8,9,10,11,12,13,14,15,16,17,18$, but very few considering the effect of $\mathrm{H}_{2}$ inhibition $^{19,20,21,41}$.

The diversity in evaluation of the results from char reactivity experiments is large. The definition of gasification rate varies among researchers and so does the criteria to select the reactivity values from the experiments. Few authors ${ }^{16,22}$ have concerns regarding this.

This study presents the kinetic parameters and reactivity profiles for steam gasification of birch and beech char. The inhibition effect of hydrogen is also studied using Langmuir-Hinshelwood kinetics. In addition, the influence of the treatment of the experimental results is analysed by comparing the kinetic parameters differently obtained from the same experiments.

The same birch char has been used for $\mathrm{CO}_{2} / \mathrm{CO}$ gasification ${ }^{23}$. The kinetic study of char gasification in $\mathrm{H}_{2} \mathrm{O} / \mathrm{H}_{2} / \mathrm{CO}_{2} / \mathrm{CO}$ mixtures will be a continuation of the work presented.

\section{THEORETICAL BACKGROUND}

\section{$\mathrm{H}_{2} \mathrm{O} / \mathrm{H}_{2} \mathrm{REACTION} \mathrm{MECHANISMS}$}

The overall steam gasification reaction can be represented by:

$$
\mathrm{C}_{f}+\mathrm{H}_{2} \mathrm{O} \rightleftharpoons \mathrm{CO}+\mathrm{H}_{2}
$$

However, the reaction is much more complex and involves several steps. Numerous studies have been conducted in order to understand the mechanisms of the steam gasification reaction. The catalytic activity of the ash plays an important role in this discussion ${ }^{24,19,25} \cdot \mathrm{H}_{2} \mathrm{O}$ gasification is more complex than $\mathrm{CO}_{2}$ gasification because not only $\mathrm{H}_{2} \mathrm{O}$ is involved but also $\mathrm{H}_{2}, \mathrm{CO}_{2}$ and $\mathrm{CO}$ due to the equilibrium of the water gas shift reaction $^{19,25}$.

Hüttinger and Merdes ${ }^{26}$ give a comprehensive description of the models proposed in the literature for the carbon-steam reaction. Basically, there are two models of the reaction mechanism: the oxygen exchange model and the hydrogen inhibition model. The equations involved are:

$$
\begin{aligned}
& C_{f}+H_{2} O \underset{k_{1 b}}{\stackrel{k_{1 f}}{\rightleftarrows}} C(O)+H_{2} \\
& C(O) \stackrel{k_{3}}{\longrightarrow} C O+C_{f} \\
& C_{f}+H_{2} \underset{k_{4 b}}{\stackrel{k_{4 f}}{\rightleftarrows}} C(H)_{2} \\
& C_{f}+\frac{1}{2} H_{2} \underset{k_{5 b}}{\stackrel{k_{5 f}}{\rightleftarrows}} C(H)
\end{aligned}
$$

The oxygen exchange model is based on equations 2 (reversible $-\mathrm{k}_{1 \mathrm{f}}$ and $\mathrm{k}_{1 \mathrm{~b}^{-}}$) and 3 , the traditional hydrogen inhibition model is based on equations 2 (irreversible -only $\mathrm{k}_{1 \mathrm{f}^{-}}$), 3 
and 4 and a different version of the hydrogen inhibition model substitutes equation 4 by equation 5. Each model has a different explanation of the inhibition effect of hydrogen. According to the oxygen exchange model, it is due to the equilibrium of the dissociation reaction (Eq. 2). For the traditional hydrogen inhibition model, the formation of the $\mathrm{C}(\mathrm{H})_{2}$ complex is the reason for inhibition. Finally, the second version of the hydrogen inhibition model involves a dissociative chemisorption of hydrogen on the active sites ${ }^{27,28}$, blocking them for the oxygen transfer reaction with steam.

The reaction rate for the models presented is similar, with the exception of dependency on hydrogen partial pressure:

$$
r_{c}=\frac{k_{1 f} p_{H 2 O}}{1+\frac{k_{1 f}}{k_{3}} p_{H 2 O}+f\left(p_{H 2}\right)}
$$

where

$$
\begin{aligned}
& f\left(p_{H 2}\right)=\frac{k_{1 b}}{k_{3}} p_{H 2}, \text { oxygen exchange model } \\
& f\left(p_{H 2}\right)=\frac{k_{4 f}}{k_{4 b}} p_{H 2}, \text { hydrogen inhibition model (traditional) } \\
& f\left(p_{H 2}\right)=\frac{k_{5 f}}{k_{5 b}} p_{H 2} 0.5, \text { hydrogen inhibition model (second version) (6.3.) }
\end{aligned}
$$

According to Hüttinger and Merdes ${ }^{26}$, it is not possible to determine which is the dominating hydrogen inhibiting mechanism by looking at the reaction rate because the equations are identical, with exception of the second version of the hydrogen inhibition model.

It is quite common to reduce equation 6 to the following expression ${ }^{20,24}$ :

$$
r=\frac{K_{1} p_{H 2 O}}{1+K_{2} p_{H 2 O}+K_{3} p_{H 2}}
$$

where $K_{2}$ and $K_{3}$ represent a ratio between rate constants but are not rate constants themselves.

Other authors ${ }^{19,29}$ rather use empirical equations to model the chemical kinetics. In this work, the kinetic parameters have been obtained according to the oxygen exchange model, equations 2 and 3 , and also according to $\mathrm{n}^{\text {th }}$ order kinetics.

\section{INFLUENCE OF FUEL TYPE}

Several studies have focused on the influence of wood type on $\mathrm{CO}_{2}$ gasification ${ }^{30,31,32}$ and steam gasification ${ }^{2,14,17,20,33,34,35}$. A general conclusion is that the ash content, composition and its catalytic properties explain the differences among the fuels. In particular, Hansen et al. ${ }^{20}$ refer to the potassium content of the ashes as being especially relevant.

Moilanen et al. ${ }^{14}$ present their results from steam atmospheric gasification of chars from different origins: wood, black liquor, cellulose fibres, peat and coal. All chars, apart from peat, present an increasing reaction rate with conversion, especially wood. 
Stoltze et al. ${ }^{17}$ find that the gasification of hardwood is 2-3 times slower than straw, probably due to the different char structure and composition. However, since the density of the hardwood char is 5 times higher than the one of straw, in a volume basis the reactivity of wood char is double than of straw. The direct consequence of this fact is that the gasifiers for wood char only require half the volume of a straw gasifier.

Finally, it is important to mention that the pyrolysis conditions also have influence on the char reactivity, as several investigations have proved.

\section{TREATMENT OF THE EXPERIMENTAL RESULTS}

There are two definitions of the reactivity commonly used:

$$
\begin{aligned}
& r=-\frac{1}{\left(m(t)-m_{f}\right)} * \frac{d\left(m(t)-m_{f}\right)}{d t} \\
& r_{w}=-\frac{1}{\left(m_{0}-m_{f}\right)} * \frac{d\left(m(t)-m_{f}\right)}{d t}
\end{aligned}
$$

where $\mathrm{m}_{\mathrm{o}}$ is the char mass at the beginning of the gasification and $\mathrm{m}_{\mathrm{f}}$ is either negligible, or represents the mass of ash, or - as in this work- the residual mass after gasification. The degree of conversion is obtained as:

$$
X(t)=1-\frac{m(t)-m_{f}}{m_{0}-m_{f}}
$$

Therefore, the relation between the two definitions of reactivity presented above is:

$$
r_{w}=r^{*}(1-X)
$$

It is widely accepted that the reactivity depends on the degree of conversion but there is no agreement about how to define one representative value of reactivity for each experiment.

The representative value of reactivity from an experiment is most frequently obtained as the average reactivity between two degrees of conversion: $0-50 \%{ }^{36}, 0$ $70 \%^{16}, 0-75 \%^{10}, 40-60 \%^{20}, 10-50 \%^{37}, 60-80 \%^{30}$.

Bandyopadhyay et al. ${ }^{38}$ selects the representative value of reactivity as the reactivity at 5\% conversion. Using an earlier value might introduce error because of the gas changing, but a later value would not correspond to a known condition of the sample inside the sample cup holder (depth, mainly).

Stoltze et al. $^{16}$ propose a mass-weighed mean reactivity in order to give less importance to the latest stages of conversion.

Finally, other researchers consider the reactivity as a function of the chemical reactivity, dependent of temperature and reactants partial pressure but independent of conversion, and of a structural factor, solely dependent on the degree of conversion ${ }^{13,39}$.

Still, it is possible to find other methods to obtain reactivity ${ }^{11,19}$. 


\section{EXPERIMENTAL SECTION}

Kinetics for a Norwegian birch and a Danish beech have been determined. Apart from their origin there are also other differences between the woods. The beech sample is first received as wood chips whose surface has been exposed to the ambient and that partially contains bark. The birch sample comes from a wood log that has been cut into small cubes of $1 \times 1 \times 1 \mathrm{~cm}$, removing the bark. The proximate and ultimate analysis is shown in Table 1 and the ash analysis in Table 2.

Table 1 Proximate and ultimate analysis of birch and beech wood.

\begin{tabular}{lrrrr}
\hline Proximate analysis & Moisture & Volatile matter & Fixed carbon & Ash \\
\hline Birch wood & $11.13 \%$ & $78.7 \%, \mathrm{mf}$ & $20.9 \%, \mathrm{mf}$ & $0.37 \%, \mathrm{mf}$ \\
Beech wood & $14.16 \%$ & $75.2 \%, \mathrm{mf}$ & $24.2 \%, \mathrm{mf}$ & $0.56 \%, \mathrm{mf}$ \\
\hline Ultimate analysis & $\mathrm{C}$ & $\mathrm{H}$ & $\mathrm{N}$ & $\mathrm{O}$ (by diff.) \\
\hline Birch wood (wt $\%, \mathrm{mf})$ & 48.7 & 6.4 & 0.078 & 44.45 \\
Beech wood (wt $\%, \mathrm{mf})$ & 48.1 & 6.4 & 0.081 & 44.82 \\
\hline \multicolumn{2}{c}{$*$ Pyrolysis conditions: Heating at $24{ }^{\circ} \mathrm{C} /$ min until $600{ }^{\circ} \mathrm{C}$, held for 30 min, natural cooling. }
\end{tabular}

Table 2 Ash analysis of birch and beech wood (\%).

\begin{tabular}{lrrrrrrrrr}
\hline Species & $\mathrm{Si}$ & $\mathrm{Al}$ & $\mathrm{Fe}$ & $\mathrm{Ca}$ & $\mathrm{Mg}$ & $\mathrm{K}$ & $\mathrm{Na}$ & $\mathrm{Ti}$ & $\mathrm{S}$ \\
\hline Beech & 1.2 & 0.14 & 1.8 & 25 & 7.1 & 28 & 2 & 0.029 & 0.75 \\
Birch & 0.03 & 0.01 & 0.17 & 30 & 4.8 & 28 & 0.08 & 0.007 & 0.64 \\
\hline Species & $\mathrm{P}$ & $\mathrm{Cl}$ & $\mathrm{Cu}$ & $\mathrm{Zn}$ & $\mathrm{Ni}$ & $\mathrm{Pb}$ & $\mathrm{Cd}$ & $\mathrm{Hg}$ & \\
\hline Beech & 2 & 0.29 & 0.03 & 0.2 & 0.02 & 0.01 & $<0.001$ & $<0.001$ & \\
Birch & 3.4 & 0.03 & 0.06 & 0.06 & 0.01 & 0.02 & $<0.001$ & $<0.001$ &
\end{tabular}

Both woods have been pyrolysed at the Technical University of Denmark, Department of Energy Engineering (DTU, ET), in a macro-TGA, heated at $24{ }^{\circ} \mathrm{C} / \mathrm{min}$ to $600{ }^{\circ} \mathrm{C}$, held at that temperature for $30 \mathrm{~min}$ and then cooled down to room temperature naturally. Both chars were thereafter crushed and sieved to 45-63 $\mu \mathrm{m}$.

The instrument used for the reactivity study is a Pressurised Thermogravimetric Analyser (PTGA) at ReaTech, a modified Du Pont Thermogravimetric Analyser. The sample $(\sim 5 \mathrm{mg})$ is placed on a small platinum tray, hanging on a horizontal balance arm. The sample temperature is measured with the help of two thermocouples, near to, but not in contact, with the sample. This investigation is limited to atmospheric pressure although the instrument is prepared for high pressure operation. Rathmann et al. $^{40}$ and Sørensen ${ }^{35}$ give a detailed description of the PTGA and Hansen et al. ${ }^{20}$ describe the modifications required for the instrument to tolerate steam.

Once the char sample is introduced into the PTGA, it is first dried in $\mathrm{N}_{2}$ during 10 min at $200{ }^{\circ} \mathrm{C}$, then is heated at $24{ }^{\circ} \mathrm{C} / \mathrm{min}$ to $1000{ }^{\circ} \mathrm{C}$ and held at this temperature for $30 \mathrm{~min}$. After this the sample is cooled to the gasification temperature and when conditions are stable, the steam is allowed into the reaction chamber. The sample is hold isothermal until the gasification reaction is complete and then the temperature is raised to $1000{ }^{\circ} \mathrm{C}$ to complete the reaction. The sample size is ca. $10 \mathrm{mg}$ and the gas flow $1000 \mathrm{ml} / \mathrm{min}$.

The objective of increasing the temperature up to $1000{ }^{\circ} \mathrm{C}$ previous to gasification is to simulate the history of the particle in the two-stage gasifier at DTU, ET. This is also the reason for the heating rate of $24{ }^{\circ} \mathrm{C} / \mathrm{min}$. During the $30 \mathrm{~min}$. period at $1000{ }^{\circ} \mathrm{C}$ 
in the nitrogen atmosphere some fraction of the catalytic species $\mathrm{K}$ and $\mathrm{Na}$ devolatilise and are carried away from the sample and therefore the char could be less reactive.

The experimental matrix for this investigation is shown in Table 3.

Table 3 Experimental matrix for $\mathrm{H}_{2} \mathrm{O}$ gasification experiments

\begin{tabular}{|c|c|c|c|c|c|c|c|c|}
\hline & \multicolumn{8}{|c|}{$\mathrm{T}\left({ }^{\circ} \mathrm{C}\right)$} \\
\hline \multirow{2}{*}{$\begin{array}{l}\mathrm{P}_{\mathrm{H} 2 \mathrm{O}} \\
\text { (bar) }\end{array}$} & 750 & \multicolumn{2}{|c|}{800} & \multicolumn{2}{|c|}{850} & \multicolumn{2}{|c|}{900} & 950 \\
\hline & & & With $\mathrm{H}_{2}$ & & with $\mathrm{H}_{2}$ & & with $\mathrm{H}_{2}$ & with $\mathrm{H}_{2}$ \\
\hline 0.1 & 00 & 000 & (1) & 000 & (1) 13 & 00 & (1) (13 & (3) 3 \\
\hline 0.3 & 0000 & 00 & 223 & 00 & 3 & O & (2) 3 & \\
\hline 0.5 & 00 & 000 & (1) 1 & 00 & (1) 1 & & (3) & (3) \\
\hline
\end{tabular}

$(\mathrm{O}, 1,(2,(3))$ Birch char; $(\boldsymbol{\bullet}, \mathbf{1}, \mathbf{2}, \mathbf{3})$ Beech char. The numbered symbols indicate the partial pressure of hydrogen (x10 bar).

The design of the installation is described in Fig. 1.

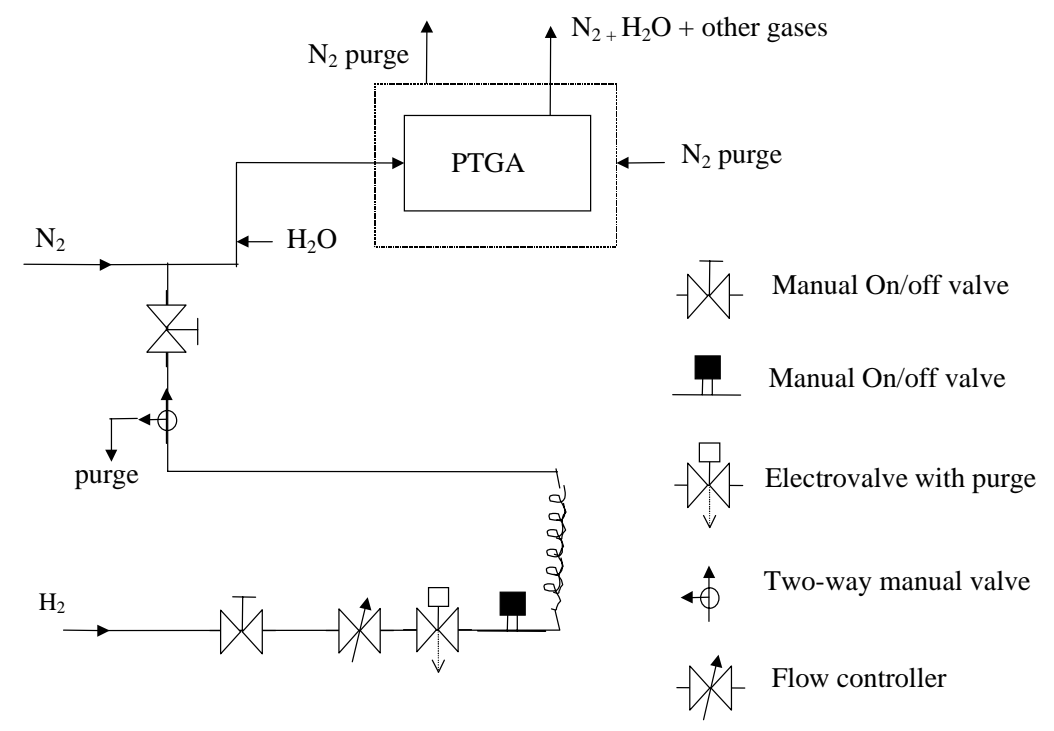

Fig. 1 Schematic drawing of the installation set-up.

\section{RESULTS AND DISCUSSION}

\section{GASIFICATION RATE}

Fig. 2 shows the mass loss curve for one of the experiments. The initial and final weights for the gasification reaction are also indicated. Fig. 3 shows the reactivity as a function of the degree of conversion, i.e. the reactivity profile, for the same experiment according to equations 8 and 9. In addition, the figure shows the average reactivity (from eq. 8 ) between 20 and $80 \%$ conversion. 
It is important to notice that the shape of the reactivity profile is very dependent on the reactivity definition. For the following discussion, the reactivity has been obtained according to equation 8 .

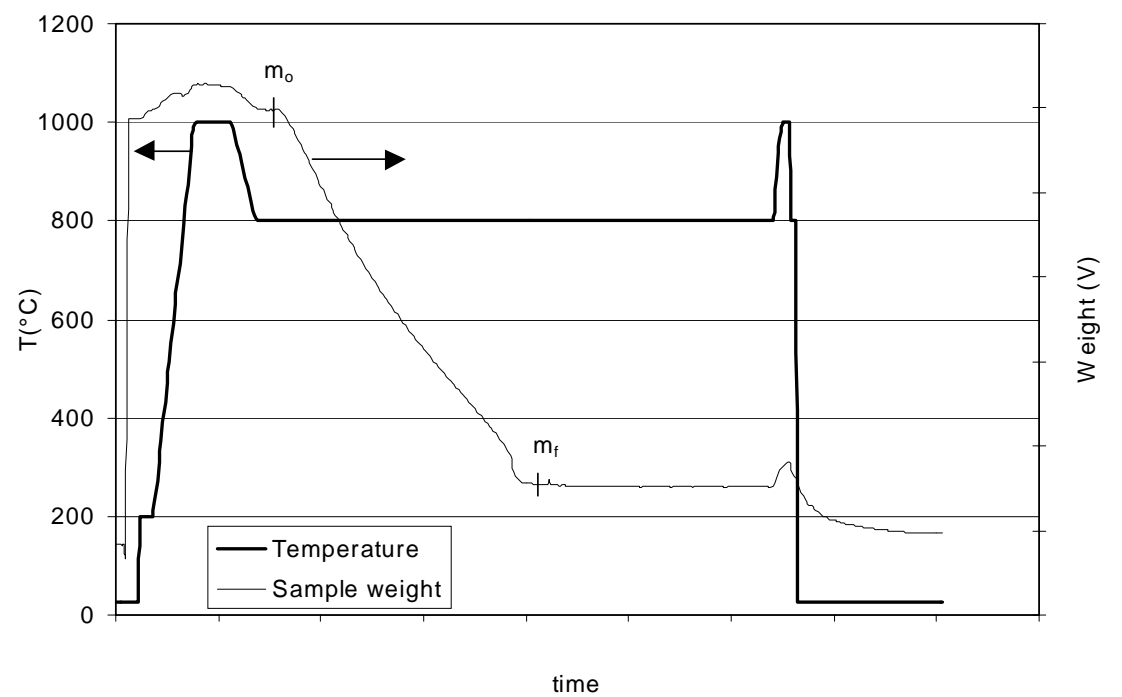

Fig. 2 Temperature and weight signal as a function of time. Experimental data.

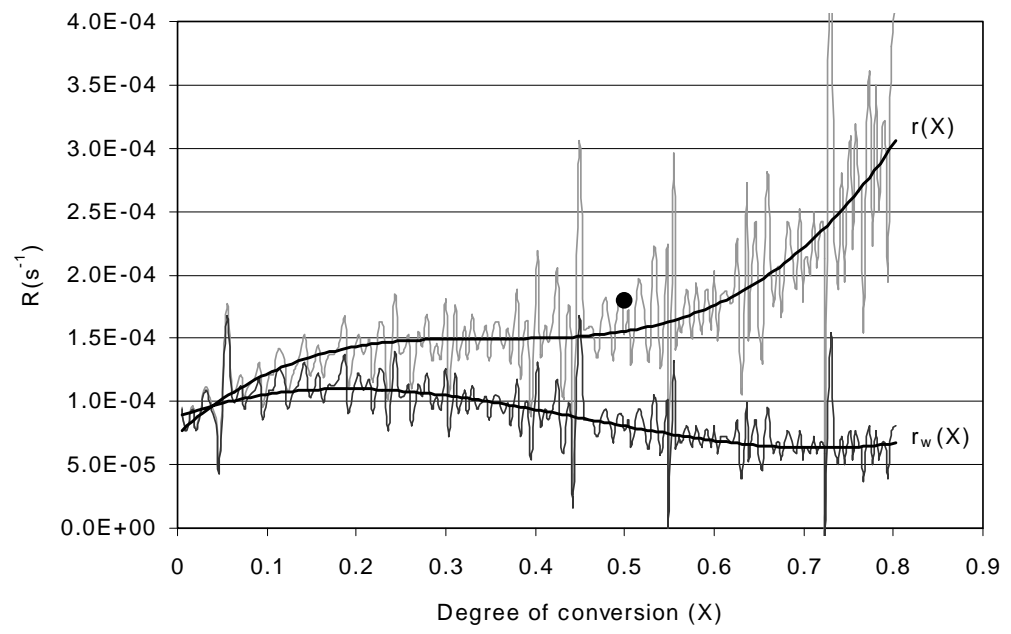

Fig. 3 Reactivity as a function of conversion.

(-: Average reactivity between 20 and $80 \%$ conversion).

\section{PURE STEAM EXPERIMENTS}

Fig. 4 shows the reactivity of the pure steam experiments as a function of temperature and steam partial pressure. The representative reactivity value has been obtained as the reactivity at $50 \%$ conversion. The continuous line shows the $\mathrm{n}^{\text {th }}$ order reaction model for the birch experiments. The figure shows that beech is more reactive than birch at 
low temperatures $\left(750-800{ }^{\circ} \mathrm{C}\right)$. The kinetic parameters obtained according to $\mathrm{n}^{\text {th }}$ order kinetics are shown in Table 4 together with results from other references.

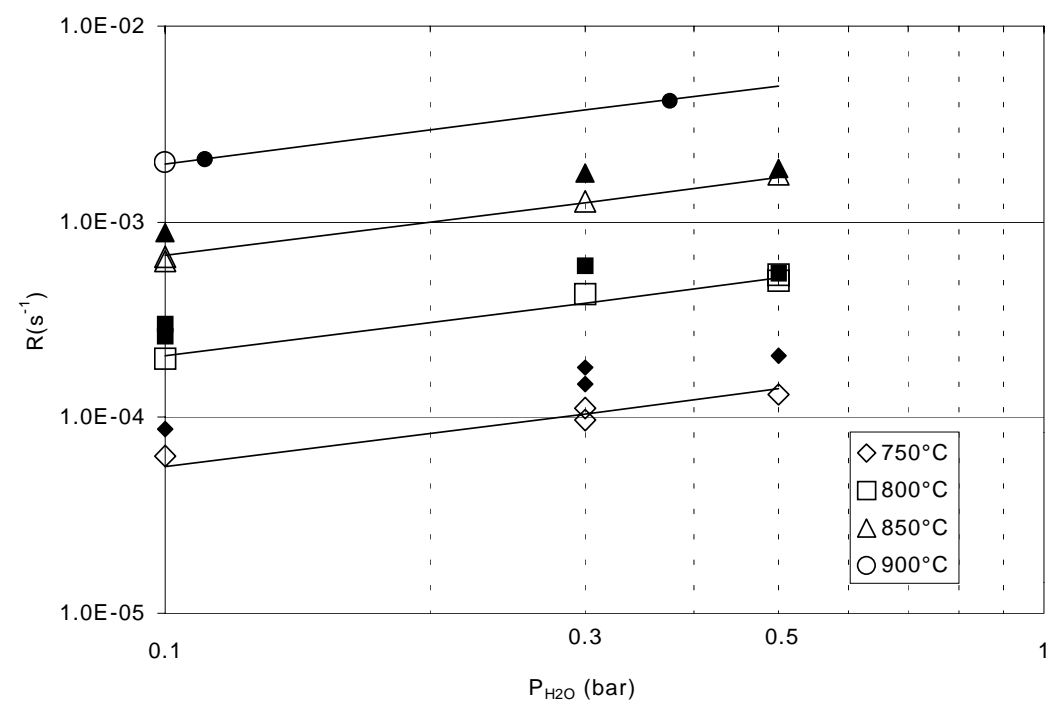

Fig. 4 Reactivity as a function of steam partial pressure and temperature. (Filled symbols: beech, hollow symbols: birch).

Table 4 Kinetic parameters comparison for steam gasification experiments.

\begin{tabular}{|c|c|c|c|c|}
\hline \multirow[b]{2}{*}{ Reference } & \multirow[b]{2}{*}{ Char origin } & \multicolumn{3}{|c|}{$\mathrm{N}^{\text {th }}$ order kinetics } \\
\hline & & $\mathrm{E}(\mathrm{kJ} / \mathrm{mol})$ & $\mathrm{k}_{\mathrm{o}}$ & $\mathrm{n}$ \\
\hline This work $^{*}$ & Birch & $237 \pm 0.4$ & $2.62 \cdot 10^{8} \pm 5 \cdot 10^{6} \mathrm{~s}^{-1} \mathrm{bar}^{-\mathrm{n}}$ & $0.57 \pm 0.03$ \\
\hline This work $^{+}$ & Beech & $211 \pm 6.1$ & $1.71 \cdot 10^{7} \pm 1 \cdot 10^{7} \mathrm{~s}^{-1} \mathrm{bar}^{-\mathrm{n}}$ & $0.51 \pm 0.05$ \\
\hline Capart et al. ${ }^{12}$ & Woodchar & 138 & $1.79 \cdot 10^{3} \mathrm{~s}^{-1} \mathrm{~atm}^{-\mathrm{n}}$ & 1.00 \\
\hline Hemati et al. ${ }^{13}$ & Woodchar & 198 & $1.23 \cdot 10^{7} \mathrm{~s}^{-1} \mathrm{~atm}^{-\mathrm{n}}$ & 0.75 \\
\hline Richard et al. ${ }^{8}$ & Fir wood & $104.5 \pm 8$ & & \\
\hline Li et al. ${ }^{9}$ & Black liquor & $210+10$ & & \\
\hline Whitty $^{19}$ & Black liquor & 230 & & 0.56 \\
\hline \multirow[t]{2}{*}{ Timpe et al. ${ }^{10}$} & Poplar & 271 & & \\
\hline & Cattails & 262 & & \\
\hline \multirow[t]{2}{*}{ Moilanen et al. ${ }^{14,15}$} & Wood & 196,217 & & \\
\hline & Black liquor & 226 & & \\
\hline \multirow{2}{*}{$\begin{array}{l}\text { Stoltze et al. }{ }^{16,17} \\
\text { (Large TGA) }\end{array}$} & Straw & 151 & $4.77 \cdot 10^{7} \% / \mathrm{min}$ & $\sim 0.5$ \\
\hline & Wood chips & 119 & $1.76 \cdot 10^{6} \% / \mathrm{min}$ & $\sim 0.5$ \\
\hline \multirow[t]{2}{*}{ Rensfelt et al. $^{2}$} & Poplar wood & 182 & $1.2 \cdot 10^{8} \mathrm{~min}^{-1}$ & \\
\hline & Straw & 182 & $5.9 \cdot 10^{7} \mathrm{~min}^{-1}$ & \\
\hline Groeneveld $^{18}$ & Wood char & 217 & $10^{6}-10^{7} \mathrm{~s}^{-1} \mathrm{~m}^{2.1} \mathrm{~mol}^{-0.7}$ & 0.7 \\
\hline
\end{tabular}

From the above comparison one can see that the activation energy varies between 105 and $270 \mathrm{~kJ} / \mathrm{mol}$. Most values for E lie between 180 and $270 \mathrm{~kJ} / \mathrm{mol}$ and the parameters obtained in this investigation are well within this range. The reaction order obtained is 
also similar to the values found in literature, eventually among the lower values. These data will be further discussed in Fig. 7.

\section{$\mathrm{H}_{2}$ INHIBITION EFFECT}

The experiments show that the presence of hydrogen inhibits the steam gasification reaction, as presented in Fig. 5.

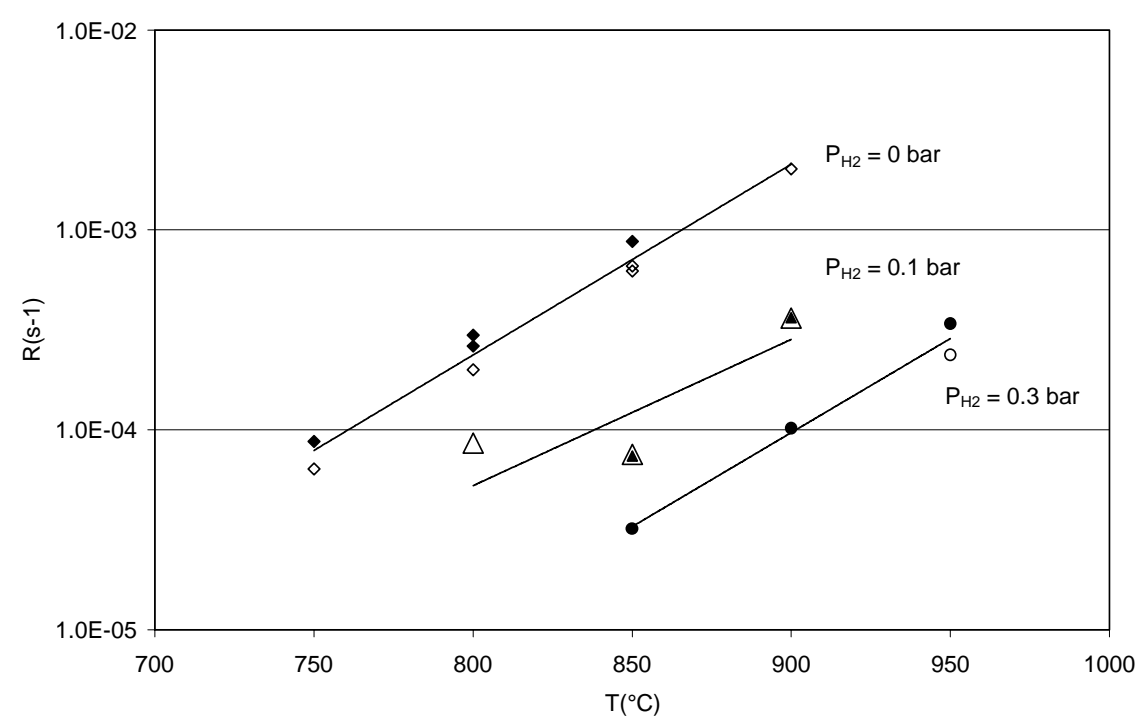

Fig. 5 Inhibition effect of $\mathrm{H}_{2}$ as a function of temperature and $\mathrm{H}_{2}$ partial pressure. $\left(\mathrm{P}_{\mathrm{H} 2 \mathrm{O}}=0.1\right.$ bar, filled symbols: beech, hollow symbols: birch $)$

The equations 6 and 6.1 have been used to model the reaction. Table 5 shows the kinetic parameters obtained in this investigation. In spite of the high uncertainty of the model parameter calculation, the model fits well the experimental results (See Fig. 6).

Table 5 Kinetic constants for $\mathrm{H}_{2} \mathrm{O} / \mathrm{H}_{2}$ gasification of birch and beech char.

\begin{tabular}{lcccccc}
\hline Wood species & $\begin{array}{c}\mathrm{E}_{1 \mathrm{f}} \\
(\mathrm{kJ} / \mathrm{mol})\end{array}$ & $\begin{array}{c}\mathrm{k}_{\mathrm{olf}} \\
\left(\mathrm{s}^{-1} \mathrm{bar}^{-1}\right)\end{array}$ & $\begin{array}{c}\mathrm{E}_{\mathrm{bb}} \\
(\mathrm{kJ} / \mathrm{mol})\end{array}$ & $\begin{array}{c}\mathrm{k}_{\mathrm{olb}} \\
\left(\mathrm{s}^{-1} \mathrm{bar}^{-1}\right)\end{array}$ & $\begin{array}{c}\mathrm{E}_{3} \\
(\mathrm{~kJ} / \mathrm{mol})\end{array}$ & $\begin{array}{c}\mathrm{k}_{\mathrm{o} 3} \\
\left(\mathrm{~s}^{-1}\right)\end{array}$ \\
\hline Beech & 199 & $2.0 \cdot 10^{7}$ & 146 & $1.8 \cdot 10^{6}$ & 225 & $8.4 \cdot 10^{7}$ \\
Birch & 214 & $7.6 \cdot 10^{7}$ & 284 & $2.1 \cdot 10^{12}$ & 273 & $1.6 \cdot 10^{10}$ \\
\hline
\end{tabular}

Table 6 compares these results with the few kinetic parameters found in the literature. Although there is a certain agreement in the value of $E_{3}$, the other values are somewhat different. This could be explained by the high uncertainty of the calculation, as also mentioned by Hansen et al. ${ }^{20}$ or by the differences in char origin. 


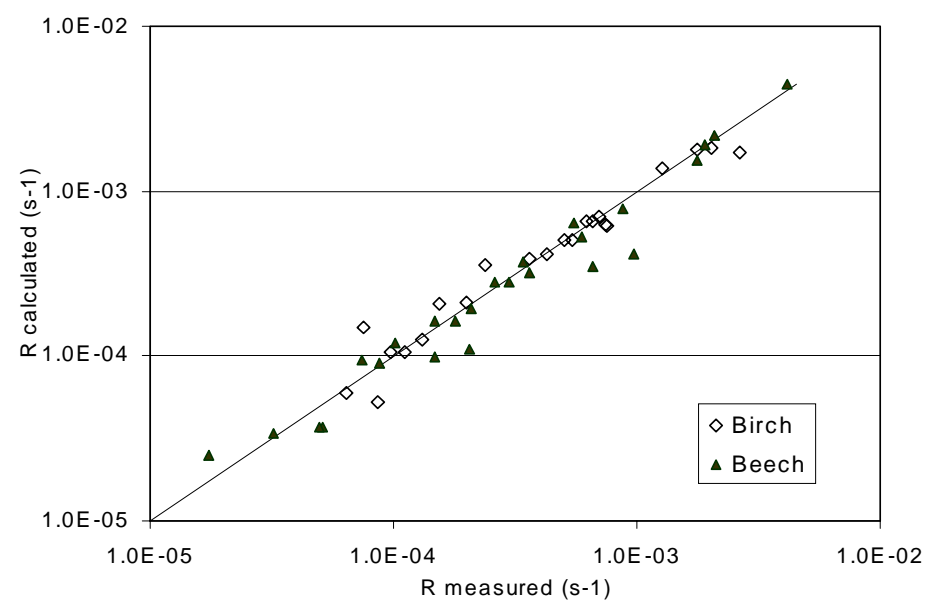

Fig. 6 Calculated reactivity values versus experimental values.

Table 6 Comparison of kinetic parameters for $\mathrm{H}_{2} \mathrm{O} / \mathrm{H}_{2}$ gasification.

\begin{tabular}{|c|c|c|c|c|c|c|}
\hline & & \multicolumn{5}{|c|}{ Langmuir-Hinshelwood kinetics } \\
\hline Reference & Char origin & $\begin{array}{c}\mathrm{E}_{\mathrm{lf}} \\
(\mathrm{kJ} / \mathrm{mol})\end{array}$ & $\begin{array}{c}\mathrm{E}_{\mathrm{lb}} \\
(\mathrm{kJ} / \mathrm{mol})\end{array}$ & $\begin{array}{c}\mathrm{E}_{3} \\
(\mathrm{~kJ} / \mathrm{mol})\end{array}$ & $\begin{array}{c}\mathrm{E}_{1 \mathrm{f}}-\mathrm{E}_{3} \\
(\mathrm{~kJ} / \mathrm{mol})\end{array}$ & $\begin{array}{c}\mathrm{E}_{1 \mathrm{~b}}-\mathrm{E}_{3} \\
(\mathrm{~kJ} / \mathrm{mol})\end{array}$ \\
\hline This work & Birch & 214 & 284 & 273 & -59 & 11 \\
\hline This work & Beech & 199 & 146 & 225 & -26 & -79 \\
\hline Hansen et al. ${ }^{20}$ & Wheat straw & 149 & $140^{*}$ & $257^{*}$ & -108 & -117 \\
\hline Sørensen et al. ${ }^{41+}$ & Wheat straw & 158 & 126 & 269 & -111 & -143 \\
\hline
\end{tabular}

Calculated values, implied in the kinetic model.

${ }^{+}$Recalculation from Hansen et al. ${ }^{20}$ experiments.

Fig. 7 compares all the kinetic parameters obtained with those found in literature, with and without hydrogen inhibition, by means of a kinetic compensation diagram. A solid line has been drawn for each of the Langmuir-Hinshelwood constant. Most of the values lie within the same line what might be a sign of consistency in spite of the disparity in activation energies. The kinetic parameters according to $\mathrm{n}^{\text {th }}$ order kinetics are somewhat more scattered although still aligned. The differences between kinetic parameters can be also due to parameters not studied in this investigation like the number of active sites or the effect of temperature on the active sites behaviour. The three sets of kinetic parameters for birch (Langmuir-Hinshelwood kinetics) represent three valid numerical solutions in the model fitting. 


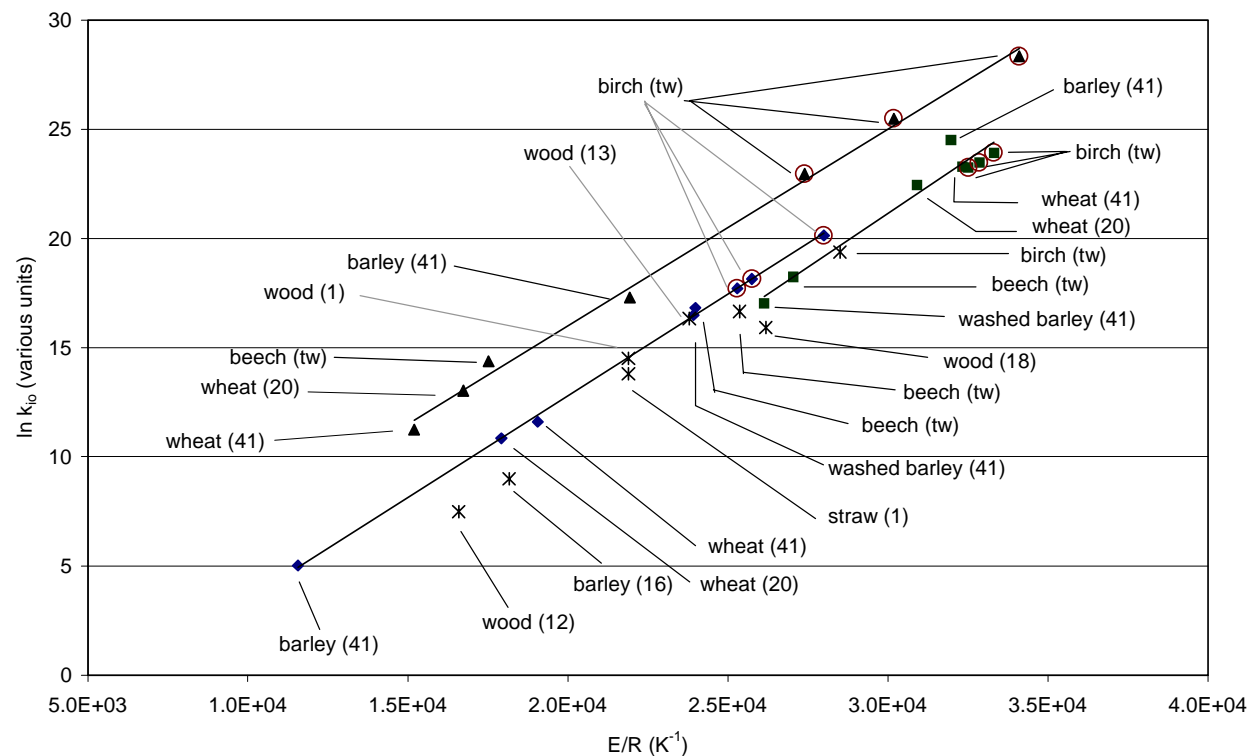

Fig. 7 Kinetic compensation diagram for $\mathrm{H}_{2} \mathrm{O}$ and $\mathrm{H}_{2} \mathrm{O} / \mathrm{H}_{2}$ gasification. (*: $\mathrm{n}^{\text {th }}$ order, $\diamond: \mathrm{k}_{1 \mathrm{f}}, \boldsymbol{\Delta}: \mathrm{k}_{1 \mathrm{~b}}, \mathbf{\square}: \mathrm{k}_{3}$, tw: this work)

\section{EFFECT OF FUEL TYPE}

With respect to reactivity, the results have shown no large differences between birch and beech. There are however certain differences regarding the effect of temperature on the reactivity profile, and the shape of the profile itself. Fig. 8 shows several reactivity profiles, normalised with respect to their reactivity at $20 \%$ conversion to allow comparison. The final increase in gasification rate is more drastic for beech than for birch, especially noticeable for beech at lower temperatures.

Moilanen and his co-workers ${ }^{14,21}$ also obtain increasing reactivity profiles with conversion, except for peat. They expect such increasing reactivity because of pore development structure, enhanced by the catalytic effect of the ash, since the ratio catalyst/carbon increases with char conversion. Stoltze et al. ${ }^{16}$ obtain similar profiles with barley straw. Rensfelt et al. ${ }^{2}$ find as well increasing reactivity with conversion, and a characteristic shape of the reactivity profile for each fuel, having each fuel the same curve independent of temperature. However, for washed barley chars, Sørensen et al. $^{41}$ find a decreasing reactivity as a function of conversion.

The ash analysis presented in Table 2 shows very similar values for the potassium content of both woods, but there is some variation regarding other ash components. It cannot be known from the experiments whether the differences in the reactivity profiles are due to these other ash components or to a different porosity evolution as the conversion proceeds. 


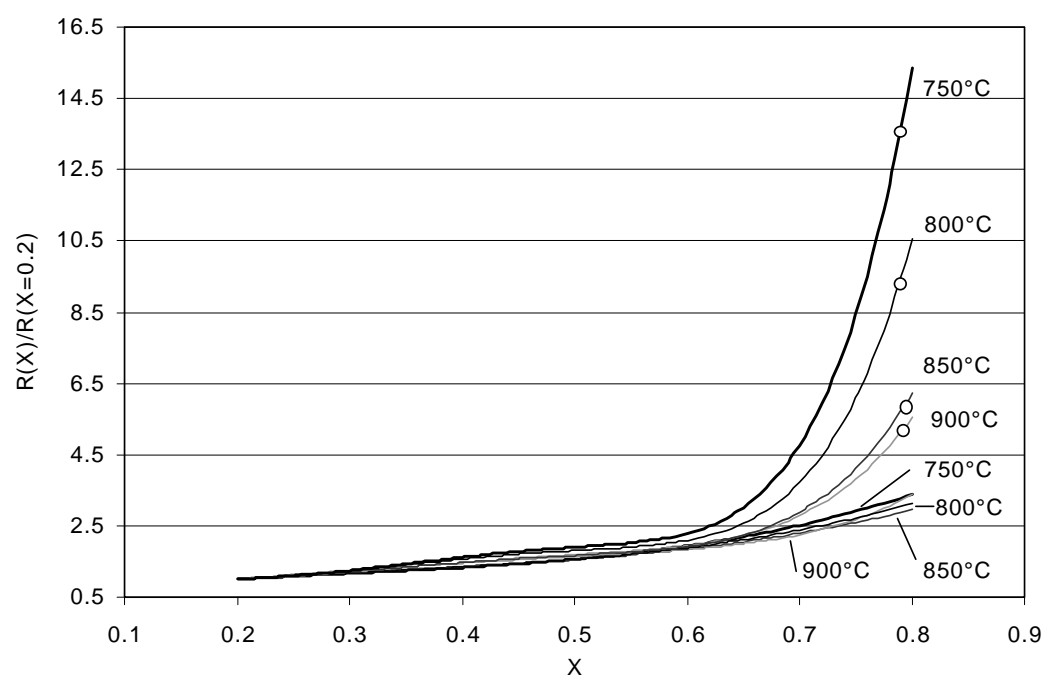

Fig. 8 Reactivity profiles for $\mathrm{H}_{2} \mathrm{O}$ experiments. (O: beech experiments).

\section{INFLUENCE OF REACTIVITY DEFINITION}

In this section, six different procedures are used to select a representative reactivity value $\left(r_{c}\right)$ from the same experiments, using the reactivity definition (eqn. 8). All the definitions are explained in Table 7.

Table 7 Representative reactivity definitions compared in this section.

\begin{tabular}{|l|l|r|l|}
\hline & Description & $X$ & Definition of $r_{c}$ \\
\hline 1 & Reactivity at 20\% conversion & 0.2 & $r_{c}=r(X=0.2)$ \\
\hline 2 & Reactivity at 50\% conv. & 0.5 & $r_{c}=r(X=0.5)$ \\
\hline 3 & Reactivity at 80\% conv. & 0.8 & $r_{c}=r(X=0.8)$ \\
\hline 4 & Average reactivity $(20-80 \%$ conv. $)$ & $0.2-0.8$ & $r_{c}=$ average $r$ between $X=0.2$ and 0.8 \\
\hline 5 & Structural profile $\mathrm{f}(\mathrm{X})$ assumed ${ }^{35,39,42}$ & $0.2-0.8$ & $\mathrm{r}=\mathrm{r}_{\mathrm{c}}\left(\mathrm{T}, \mathrm{P}_{\mathrm{H} 2 \mathrm{O}}\right) * \mathrm{f}(\mathrm{X})$ \\
\hline 6 & Time for $80 \%$ conversion & $0-0.8$ & $\mathrm{r}_{\mathrm{c}}=1 / \mathrm{t}(\mathrm{X}=0.8)$ \\
\hline
\end{tabular}

The kinetic parameters for the $\mathrm{n}^{\text {th }}$ order kinetic model have been obtained using these definitions of reactivity for the pure steam gasification experiments of birch. All the activation energies lie between $228-238 \mathrm{~kJ} / \mathrm{mol}$ and the reaction orders between 0.54 and 0.58 , apart from definition 3 . The frequency factors are somewhat more scattered, lying between $5 \cdot 10^{7}$ and $3 \cdot 10^{8}$. Regarding the uncertainty of the calculation, definitions 2, 5 and 4 seem to give more precise results and it is interesting to notice that the error of the reaction order calculation does not depend on how a representative reactivity value is defined.

It is very important to analyse the influence of the reactivity definition (eqn. 8 and 9) on the kinetic parameters. Since all representative reactivity definitions are related to a fixed degree of conversion (or a fixed interval), the difference between $r$ and $r_{w}$ will be a multiplying factor, independent of temperature and pressure, and therefore absorbed in the frequency factor. This means that whether equation 8 or 9 is used, the activation energy and the reaction order calculation will give the same result. 


\section{CONCLUSIONS}

(1) The kinetic parameters according to the $\mathrm{n}^{\text {th }}$ order reaction model for steam gasification of wood char are $\mathrm{E}=237 \mathrm{~kJ} / \mathrm{mol}, \mathrm{k}_{0}=2.62 \cdot 10^{8}$ and $\mathrm{n}=0.57$ for birch, $\mathrm{E}=211 \mathrm{~kJ} / \mathrm{mol}, \mathrm{k}_{0}=1.71 \cdot 10^{7}$ and $\mathrm{n}=0.51$ for beech char.

(2) Hydrogen inhibits the steam gasification reaction. The char gasification reaction with steam and hydrogen can be modelled based on Langmuir-Hinshelwood kinetics. The model fits well the results.

(3) The type of wood affects very little the kinetic parameters but shows some influence on the reactivity profile.

(4) The definition of the reactivity will not affect the activation energy or the reaction order calculation.

(5) The method to select a representative reactivity value from one experiment has more influence on the frequency factor than on the activation energy and reaction order. The accuracy of the calculation might also be affected.

\section{ACKNOWLEDGMENTS}

The work was supported by the Norwegian Research Council, the Danish Ministry of Energy and EK Energy A.m.b.A. The authors want to thank Torben D. Pedersen, Peter Mørk and Torben Lyngbech for their help during the experimental work.

\section{REFERENCES}

1. Gil, J., Aznar, M.P., Caballero, M.A., Francés, E. \& Corella, J. (1997). Biomass gasification in fluidized bed at pilot scale with steam-oxygen mixtures. Product distribution for very different operating conditions, Energy and Fuels, Vol. 11, pp. 1109-1118.

2. Rensfelt, E., Blomkuist, G., Ekstrom, S., Espenäs, B.G. \& Liinanki, L. (1978). Basic gasification studies for development of biomass medium-btu gasification processes, Energy from Biomass and Wastes, IGT, 14-18 August 1978. Paper No. 27, pp. 466-494.

3. Bilbao, R., García, L., Salvador, M.L. \& Arauzo, J. (1998). Steam gasification of biomass in a fluidized bed, effect of a Ni-Al catalyst, Biomass for Energy and Industry. $10^{\text {th }}$ European Conference and Technology Exhibition, 8-11 June 1998, Würzburg, Germany, pp. 1708-1711.

4. Rapagnà, S., Jand, N. \& Foscolo, P.U. (1998). Utilisation of suitable catalysts for the gasification of biomasses, Biomass for Energy and Industry. $10^{\text {th }}$ European Conference and Technology Exhibition, 8-11 June 1998, Würzburg, Germany, pp. 1720-1723.

5. Evans, R., Knight, R. A., Onischak, M. \& Babu, S.P. (1987). Process performance and environmental assessment of the Renugas process, Energy from Biomass and Wastes X, IGT, pp. 677-696.

6. Paisley, M.A. et al. (1999). Commercial demonstration of the Battelle/FERCO biomass gasification process: Startup and initial operating experience,Proceedings of the $4^{\text {th }}$ Biomass Conference of the Americas, Oakland, CA,USA, pp.1061-1066.

7. Zschetzsche, A., Hofbauer, H. \& Schmidt, A. (1998). Biomass gasification in an internal circulating fluidized bed, Proceedings of the $8^{\text {th }} \mathrm{EC}$ on Biomass for Agriculture and Industry, Vol. 3, pp. 1771-1777. 
8. Richard, J.R., Cathonnet, M. \& Rouan, J.P. (1982). Gasification of charcoal: Influence of water vapor, Fundamentals of Thermochemical Biomass Conversion, pp. 589-599. Elsevier Applied Science Publishers.

9. Li, J. \& van Heiningen, A.R.P. (1991). Kinetics of gasification of black liquor char by steam,Industrial \& Engineering Chemistry Research, Vol. 30, No, 7, pp. 15941601.

10. Timpe, R.C. \& Hauserman, W.B. (1993). The catalytic gasification of hybrid poplar and common cattail plant chars, Energy from Biomass and Wastes XVI, Institute of Gas Technology, March 2-6, 1992, pp. 903-919.

11. Kojima, T., Assavadakorn, P. \& Furusawa, T. (1993).Measurement and evaluation of gasification kinetics of sawdust char with steam in an experimental fluidized bed, Fuel Processing Technology, Vol. 36, pp. 201-207.

12. Capart, R. \& Gélus, M. (1988). A volumetric mathematical model for steam gasification of wood char at atmospheric pressure, Energy from Biomass 4. Proceedings of the 3rd contractors'meeting, Paestum, 25-27 May, pp. 580-583.

13. Hemati, M. \& Laguerie, C. (1988). Determination of the kinetics of the wood sawdust Steam-gasification of charcoal in a thermobalance, Entropie, No. 142, pp. 29-40.

14. Moilanen, A., Saviharju, K. \& Harju, T. (1993). Steam gasification reactivities of various fuel chars, Advances in Thermochemical Biomass Conversion, Blackie Academic \& Professional, 1993, pp. 131-141.

15. Moilanen, A. \& Saviharju, K. (1997). Gasification reactivities of biomass fuels in pressurised conditions and product gas mixtures, Developments in Thermochemical Biomass Conversion, Blackie Academic \& Professional, 1997, pp 828-837.

16. Stoltze, S., Henriksen, U., Lyngbech, T. \& Christensen, O. (1993). Gasification of straw in a large-sample TGA, Nordic Seminar on Solid Fuel Reactivity, Chalmers University of Technology, Gothenburg, Sweden, 24 November 1993.

17. Stoltze, S., Henriksen, U., Lyngbech, T. \& Christensen, O. (1994). Gasification of straw in a large-sample TGA, Part II Nordic Seminar on Biomass Gasification and Combustion, NTH, Trondheim, 21 June 1994.

18. Groeneveld, M.J. (1980). The co-current moving bed gasifier, Ph.D.thesis, Twente University of Technology, Enschede, Netherlands.

19. Whitty, K.J. (1997). Pyrolysis and gasification behaviour of black liquor under pressurized conditions, Academic Dissertation, Report 97-3, Åbo Akademi, Department of Chemical Engineering.

20. Hansen, L.K., Rathmann, O., Olsen, A. \& Poulsen, K.(1997). Steam gasification of wheat straw, barley straw, willow and giganteus, Risø National Laboratory, Optics and Fluid Dynamics Department, Project No. ENS-1323/95-0010

21. Moilanen, A. \& Mühlen, H.J. (1996). Characterization of gasification reactivity of peat char in pressurized conditions. Effect of product gas inhibition and inorganic material, Fuel, Vol. 75, No. 11, pp. 1279-1285.

22. Whitty, K.J. (1993). Gasification of black liquor char with $\mathrm{H} 2 \mathrm{O}$ under pressurized conditions, Report 93-4, Department of Chemical Engineering, Combustion Chemistry Research Group.

23. Barrio, M.\& Hustad, J.E. CO2 gasification of birch char and the effect of CO inhibition on the calculation of chemical kinetics, This conference.

24. Mühlen, H-J., van Heek, K.H. \& Jüntgen, H. (1985). Kinetic studies of steam gasification of char in the presence of $\mathrm{H} 2, \mathrm{CO} 2$ and $\mathrm{CO}$, Fuel, Vol.64, July, pp. 944-949. 
25. Meijer, R., Kapteijn, F. \& Moulijn, J.A.(1994).Kinetics of the alkali-carbonate catalysed gasification of carbon: $\mathrm{H}_{2} \mathrm{O}$ gasification, Fuel,Vol.73,No.5, pp.723-730.

26. Hüttinger, K.J. \& Merdes, W.F. (1992). The carbon-steam reaction at elevated pressure: formations of product gases and hydrogen inhibitions, Carbon, Vol. 30, No. 6, pp. 883-894.

27. Weeda, M., Abcouwer, H.H., Kapteijn, F. \& Moulijn, J.A. (1993).Steam gasification kinetics and burn-off behaviour for a bituminous coal derived char in the presence of $\mathrm{H}_{2}$, Fuel Processing Technology, Vol. 36, pp. 235-242.

28. Linares-Solano, A., Mahajan, O.P. \& Walker, P.L. (1979). Reactivity of heattreated coals in steam, Fuel, Vol. 58, May, pp. 327-332.

29. Liliedahl, T. \& Sjöström, K. (1997). Modelling of char-gas reaction kinetics, Fuel, Vol. 76, No. 1, pp. 29-37.

30. DeGroot, W.F. \& Shafizadeh, F.(1984). Kinetics of gasification of Douglas Fir and cottonweed chars by carbon dioxide, Fuel, Vol. 63, February, pp. 210-216.

31. Kannan, M.P. \& Richards, G.N.(1990). Gasification of biomass chars in carbon dioxide: dependence of gasification rate on the indigenous metal content. Fuel, Vol. 69, June, pp. 747-753.

32. Illerup, J.B.\& Rathmann, O.(1995).CO2 gasification of Wheat straw, barley straw, willow and giganteous, Department of Combustion Research, RIS $\varnothing$ National Laboratory, 12th December.

33. Espenäs, B.G. (1993). Reactivity of biomass and peat chars formed and gasified at different conditions, Advances in Thermochemical Biomass Conversion, Blackie Academic \& Professional, 1993, pp. 142-159.

34. Moilanen, A. \& Kurkela, E. (1995). Gasification reactivities of solid biomass fuels, Preprints of papers, American Chemical Society, Division of Fuel Chemistry, Vol. 40(3), pp. 688-693.

35. Sørensen, L.H.(1994). Fuel reactivity as a function of temperature, pressure and conversion, Ph.D. thesis, Risø National Laboratory, Denmark.

36. Chen, G., Yu, Q. \& Sjöström, K.(1997). Reactivity of char from pyrolysis of birch wood, Journal of Analytical and Applied Pyrolysis, Vol. 40-41, pp. 491-499.

37. Zanzi, R., Sjöström, K. \& Björnbom, E. (1995). Rapid pyrolysis of agricultural residues at high temperature, Proceedings of the $2^{\text {nd }}$ Biomass Conference of he Americas: Energy, Environment, Agriculture, pp. 630-636.

38. Bandyopadhyay, D., Chakraborti, N. \& Ghosh, A.(1991). Heat and mass transfer limitations in gasification of carbon by carbon dioxide, Steel Research, Vol. 62, No. 4, pp. 143-151.

39. Sørensen, L.H., Gjernes, E., Jessen, T. \& Fjellerup, J. (1996). Determination of reactivity parameters of model carbons, cokes and flame-chars, Fuel, Vol. 75, No. 1, pp. 31-38.

40. Rathmann, O., Stoholm, P. \& Kirkegaard, M. (1995). The pressurized thermogravimetric analyzer at the Department of Combustion Research,, Ris $\varnothing$ : Technical description of the instrument, Roskilde: Ris $\varnothing$ National Laboratory, Ris $\varnothing-\mathrm{R}-823(\mathrm{EN})$, Denmark.

41. Sørensen, L.H. et al. (1997). Straw - H2O gasification kinetics. Determination and discussion, Nordic Seminar on Thermochemical Conversion of Solid Fuels, $3^{\text {rd }}$ December, 1997, Chalmers University of Technology, Sweden.

42. Risnes, H., Sørensen, L.H. \& Hustad, J.E. $\mathrm{CO}_{2}$ reactivity of char from Danish wheat, Norwegian spruce and Longyear coke. This conference. 